\title{
Pelatihan Usaha Tani Microgreens bagi Ibu Rumah Tangga
}

\author{
Microgreens Farming Business Training for Housewives
}

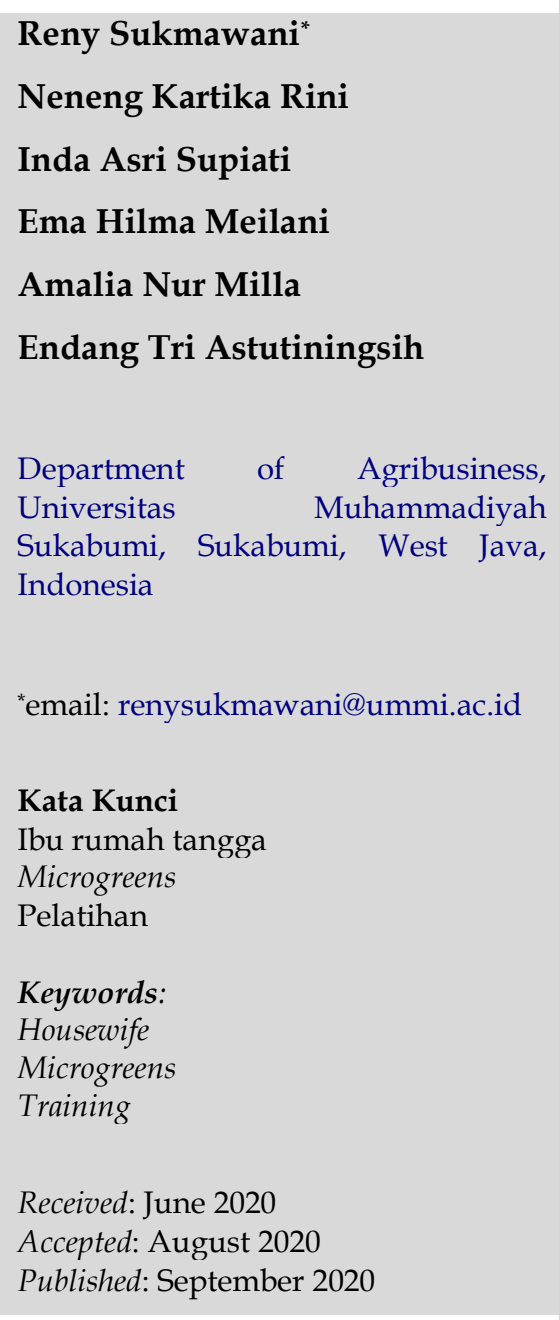

\begin{abstract}
Abstrak
Pengabdian Kepada Masyarakat ini berjudul Pelatihan Usaha Tani Microgreens Bagi Ibu Rumah Tangga di Sukabumi. Pemberdayaan ibu rumah tangga dimaksudkan untuk memproduktifkan potensi ibu rumah tangga, selain mampu melaksanakan tugas-tugas kewajiban domestik atau di dalam rumah tangga. Ibu rumah tangga juga mampu aktif dan produktif dalam kegiatan publik dan kegiatan Ekonomi. Microgreens adalah bibit sayuran yang dipanen saat masih sangat muda, berkisar 7-14 hari setelah mulai berkecambah dan muncul daun mudanya. Metode yang digunakan dalam pengabdian ini adalah metode training, yakni sebelum melaksanakan praktik langsung, peserta diberikan pemahaman melalui teori terlebih dahulu. Peserta pelatihan yakni Ibu rumah tangga dari beberapa organisasi wanita yang ada di Sukabumi. Hasil akhir dari pengabdian kepada masysrakat ini adalah diperolehnya keterampilan kaum ibu rumah tangga dalam usaha tani Microgreens serta meningkatnya peran ibu rumah tangga dalam kesejahteraan keluarga melalui penyediaan sayuran sehat bagi keluarga.
\end{abstract}

\begin{abstract}
This Community Service is entitled Microgreens Farming Business Training for Housewives in Sukabumi. The empowerment of housewives is intended to produce the potential of housewives, in addition to being able to carry out domestic or domestic duties. Housewives are also able to be active and productive in public activities and economic activities. Microgreens are vegetable seeds that are harvested very young, 7-14 days after germinating and young leaves appear. The method used in this service is the training method; namely, before carrying out direct practice, participants understand through theory first. The training participants were housewives from several women's organizations in Sukabumi. This community service is the acquisition of skills of housewives in farming microgreens and the increasing role of housewives in family welfare through the provision of healthy vegetables for the family.
\end{abstract}

(C) 2020 Reny Sukmawani, Neneng Kartika Rini, Inda Asri Supiati, Ema Hilma Meilani, Amalia Nur Milla, Endang Tri Astutiningsih. Published by Institute for Research and Community Services Universitas Muhammadiyah Palangkaraya. This is Open Access article under the CC-BY-SA License (http://creativecommons.org/licenses/by-sa/4.0/). DOI: https://doi.org/10.33084/pengabdianmu.v5i4.1436

\section{PENDAHULUAN}

Sumber daya manusia merupakan modal yang sangat penting dalam pembangunan suatu bangsa. Dampak kegiatan pemberdayaan kepada masysrakat adalah kemandirian masyarakat dalam mengatasi permasalahan mereka melalui prakarsa dan kreatifitas untuk meningkatkan kualitas hidup (Irsyadillah, 2014). Potensi perempuan pada usia kerja meskipun sudah berumah tangga sebetulnya sangat besar, mengingat peranannya yang sangat penting dalam memberdayakan keluarga (Foilyani et al., 2009). Kemandirian perempuan dapat mendorong peran serta keluarga dalam upaya meningkatkan perekonomian masyarakat, melalui peningkatan pengetahuan, keterampilan, dan motivasi yang tinggi untuk maju (Manembu, 2017).

Program Studi Agribisnis melalui ADC (Agribusiness Development Center) yang terdiri dari kegiatan 
Training/Pelatihan, Inkubasi bisnis, Riset dan kajian adalah merupakan sebuah wadah pemberdayaan membangun sumberdaya manusia dengan ciri khas "bottom up program" yang mengusung kemandirian, dan pemanfaatan sumberdaya serta potensi lokal sebagai sumber solusi. ADC Program Studi Agribisnis Fakultas Pertanian Universitas Muhammadiyah Sukabumi merupakan forum silaturahmi, komunikasi, edukasi dan sebagai wadah koordinasi kegiatan penguatan fungsi mahasiswa, kaum wanita, masyarakat pada umumnya,secara terpadu. Penguatan fungsi-fungsi utama tersebut diharapkan memungkinkan setiap mahasiswa, kaum wanita, serta masyarakat makin mampu membangun dirinya menjadi sejahtera, berdaya, mandiri dan sanggup menghadapi tantangan masa depan dengan lebih baik (Sya'roni, 2002).

Program ADC di Program Studi Agribisnis diprioritas pada bidang ekonomi/kewirausahaan. Salah satu pelatihan yang diberikan adalah usaha tani microgreens pada ibu rumah tangga. Microgreens adalah sayuran mini dari aneka tanaman sayur. Semua jenis bibit sayur yang berdaun bisa dikembangkan dan dibudidayakan menjadi tanaman microgreens (Widiwurjani et al., 2019; Febriani et al., 2019; Renna \& Paradiso, 2020), seperti ditunjukkan pada Gambar 1.

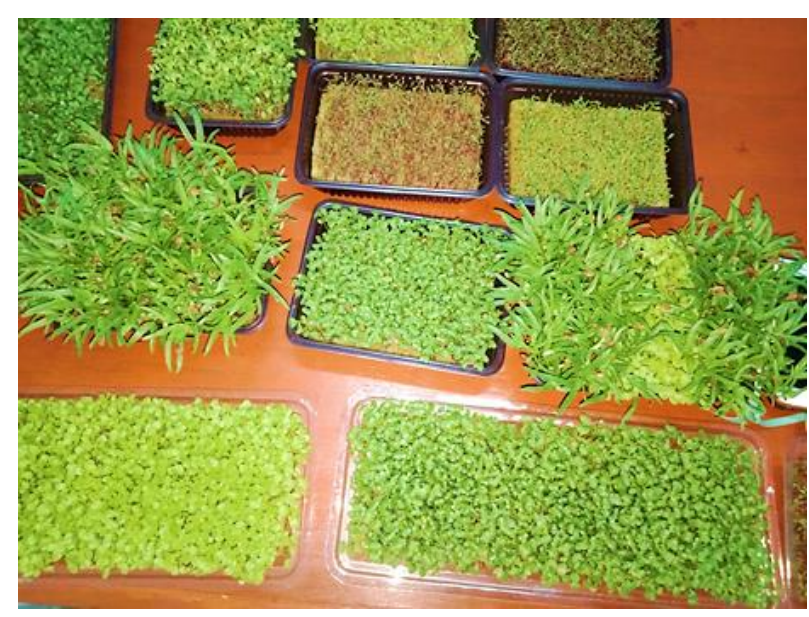

Gambar 1. Microgreens
Waktu penanaman microgreens sangat singkat, hanya butuh waktu 14 hari sampai bisa dipanen. Microgreens adalah tanaman muda, empuk, dan dapat dimakan langsung atau dipanen sebagai bibit. Microgreens ini memiliki nilai tnggi secara ekonomi sehingga menarik untuk diusahakan (Hong \& Gruda, 2020; Mir et al., 2017; Pinto et al., 2015). Bahkan sayuran microgreens memiliki nutrisi dan vitamin yang lebih banyak dibandingkan dengan sayuran yang dipanen pada usia normal (Turner et al., 2020). Hal inilah yang mendasari dipilihnya pelatihan usaha tani microgreens dalam kegiatan pengabdian kepada masysarakat Prodi Agribisnis Fakultas Pertanian Universitas Muhammadiyah Sukabumi tahun pelaksanaan 2019. Disamping pertimbangan lainnya adalah berdasarkan perkembangan gaya hidup dan pola konsumsi terhadap makanan sehat di masyarakat semakin berkembang khususnya terhadap sayuran sehat. Disisi lain, lahan usaha tani semakin terbatas, sehingga usaha tani microgreens dapat menjadi salah satu solusi (Hamzens \& Moestopo, 2018).

Pengabdian kepada masysrakat melalui pelatihan microgreens ini belum pernah dilaksanakan di Sukabumi baru dilaksanakan oleh tim pengadi dari Prodi Agribisnis, Fakultas Pertanian Universitas Muhammadiyah Sukabumi. Kegiatan dilaksanakan di Sukabumi dengan sasaran kegiatan pelatihan adalahibu rumah tangga. Pilihan ini didasarkan pada perlunya ibu rumah tangga diberdayakan, karena sebagai sumberdaya insani, potensi yang dimiliki ibu rumah tangga dalam hal kuantitas maupun kualitas cukup baik. Melalui usaha tani microgreens ibu rumah tangga minimal dapat memenuhi kebutuhan akan sayuran sehat bagi keluarga, maksimalnya bagi masyarakat. Tujuan dilaksanakannya pengabdian kepada masyarakat ini adalah mengenalkan usaha tani microgreens pada ibu rumah tangga, meningkatkan 
kualitas peran dan kemandirian perempuan dalam ketahanan pangan keluarga, mengembangkan usaha pemberdayan ibu rumah tangga dan kesejahteraan Keluarga, dan mengembangkan usaha tani yang sehat dan ramah lingkungan.

\section{METODOLOGI}

Alat dan bahan yang diperlukan dalam usaha tani microgreens sangat sederhana dan terjangkau. Bahkan sebagian dapat memanfaatkan alat dan bahan yang tersedia di rumah tanpa harus membeli. Alat dan bahan tersebut meliputi: gergaji kecil, penggaris, gelas air mineral, benih sayuran, media tanam (rockwool/cocopeat/tanah steril), pot (dapat berupa apa saja yang tersedia di rumah), dan sprayer, sebagaimana ditunjukkan pada Gambar 2.

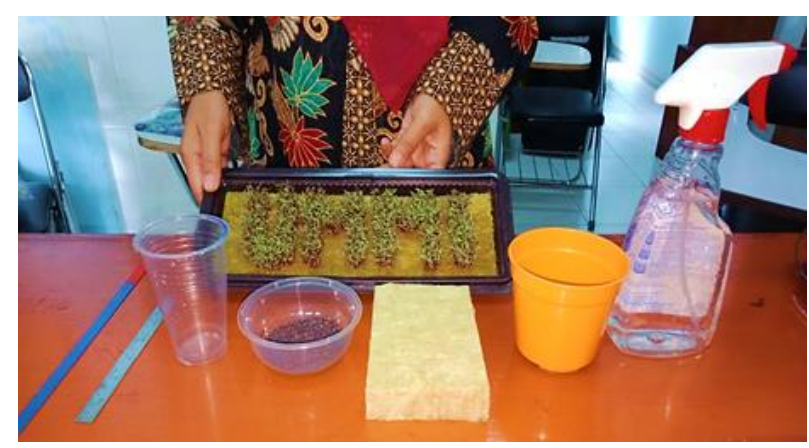

Gambar 2. Alat dan Bahan untuk Microgreens

Tahapan kegiatan pengabdian pelatihan usaha tani microgreens adalah sebagai berikut: Persiapan kegiatan, koordinasi dengan mitra sebagai kelompok sasaran kegiatan.

1. Training of Trainer (ToT) calon fasilitator

2. Pelaksanaan pelatihan pada enam kelompok sasaran dalam waktu enam bulan

\section{Publikasi}

Enam kelompok sasaran kegiatan adalah ibu rumah tangga yang tergabung dalam organisasi wanita yang ada di Sukabumi yaitu perwakilan dari Pimpinan Ranting Aisyiyah Cigunung, Pimpinan Daerah Aisyiyah
Kabupaten Sukabumi, Pimpinan Daerah Aisyiyah Kabupaten Sukabumi, Gabungan Organisasi Wanita Kota Sukabumi, dan Dharma Wanita Persatuan Kabupaten Sukabumi.

Pelaksanaan kegiatan menggunakan metode Training. Training diawali dengan pemberian materi mengenai microgreens, manfaat microgreens, langkah-langkah dalam usaha tani microgreens hingga cara untuk menyajikan microgreens yang siap dikonsumsi. Setelah peserta mendapatkan materi dilanjutkan dengan praktek langsung secara individu melalui bimbingan fasilitator. Lebih jelas tahapan kegiatan sebagai berikut:

1. Pemberian materi pengenalan microgreens dan usaha taninya hingga cara penyajian

2. Demonstrasi langkah-langkah dalam usaha tani microgreens dan cara menyajikannya

3. Praktik per individu

4. Monitoring pertumbuhan microgreens hasil praktik peserta

5. Evaluasi dan tindak lanjut

\section{HASIL DAN PEMBAHASAN}

Usaha tani tanaman mini microgreens tidak memerlukan lahan luas, sehingga semua warga perkotaan bisa menanam di rumah masing-masing. Usaha tani microgreens sendiri merupakan teknik pertanian yang paling sederhana bagi kaum urban yang tinggal di perkotaan dibanding dengan teknik pertanian lainnya. Usaha tani microgreens ini bila dilatihkan dengan baik dapat diterapkan oleh siapa saja tak terbatas usia. Metodenya paling mudah dibandingkan metode usaha tani lainnya. Hal inilah yang menyebabkan kegiatan pengabdian masyarakat melalui pelatihan microgreens bagi ibu rumah tangga ini dapat berhasil dengan baik. Terdapat empat indikator keberhasilan yang direncanakan dari kegiatan ini sebagaimana ditampilkan pada Tabel I. 
Tabel I. Indikator Keberhasilan Kegiatan

\begin{tabular}{clcc}
\hline No & \multicolumn{1}{c}{ Indikator } & Sebelum (\%) & Sesudah (\%) \\
\hline 1 & $\begin{array}{l}\text { Terlaksananya } \\
\text { program yang } \\
\text { dirancang }\end{array}$ & 0 & 100 \\
2 & $\begin{array}{l}\text { Tingkat partisipasi } \\
\text { aktif peserta } \\
\text { program }\end{array}$ & 0 & 100 \\
3 & $\begin{array}{l}\text { Meningkatnya } \\
\text { keterampilan ibu } \\
\text { rumah tangga dalam } \\
\text { usaha tani } \\
\text { microgreens } \\
\text { Bertambahnya } \\
\text { ketahanan pangan } \\
\text { keluarga }\end{array}$ & 0 & 80 \\
\hline
\end{tabular}

Hasil kegiatan menunjukan bahwa semua indikator tersebut pada Tabel I dapat tercapai sesuai dengan harapan. Peserta yang diundang semua hadir sesuai target dan berpartisipasi secara aktif. Peserta pelatihan yang mayoritas ibu rumah tangga ini mengikuti kegiatan pelatihan dengan sangat antusias. Para peserta pelatihan juga menguasai hasil pelatihan yang diberikan terbukti dengan keberhasilan dalam mempraktikkan secara mandiri bagaimana usaha tani microgreens hingga menyajikannya untuk siap dikonsumsi langsung. Dokumentasi pemberian materi disajikan pada Gambar 3.

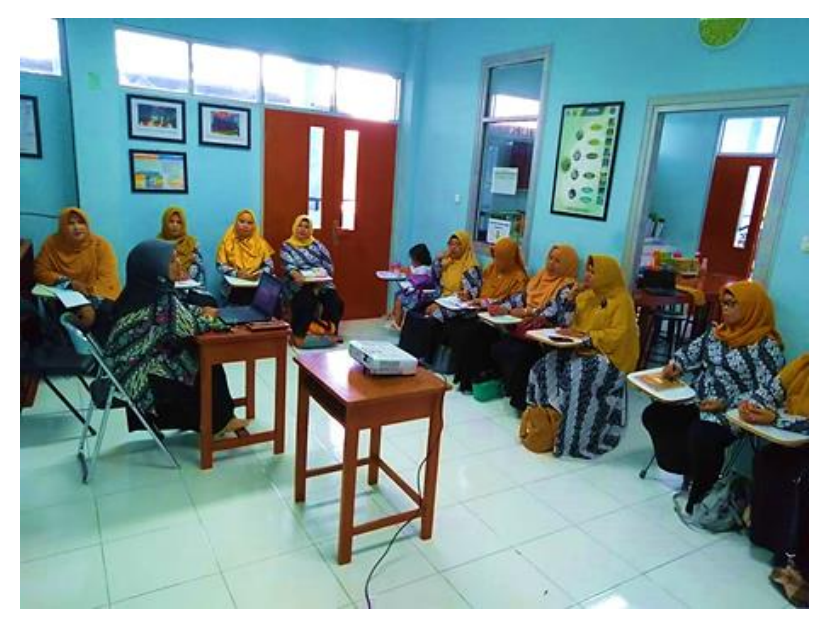

Gambar 3. Pemberian materi microgreens pada peserta dari Pimpinan Ranting Aisyiyah Cigunung oleh Dr. Reny Sukmawani, M.P.

Semua tim Dosen pada kegiatan pelatihan microgreens ini terlibat secara aktif menjadi narasumber yang dibantu oleh fasilitator dari laboran dan tim mahasiswa. Secara bergiliran pelatihan dilaksanakan kepada pada ibu rumah tangga dari perwakilan berbagai organisasi wanita yang ada diSukabumi (Kota maupun Kabupaten Sukabumi). Pemberian materi berupa teori biasanya dilaksanakan selama 60 menit yang dilengkapi dengan demontrasi oleh fasilitator. Kemudian dilanjutkan dengan praktik per individu selama 60 menit juga. Pada kegiatan praktik, semua peserta dibimbing dan diarahkan langsung oleh fasilitator sehingga dipastikan semua peserta dapat melaksanakan praktik dengan baik hingga terampil. Dokumentasi kegiatan praktik disajikan pada Gambar 4.

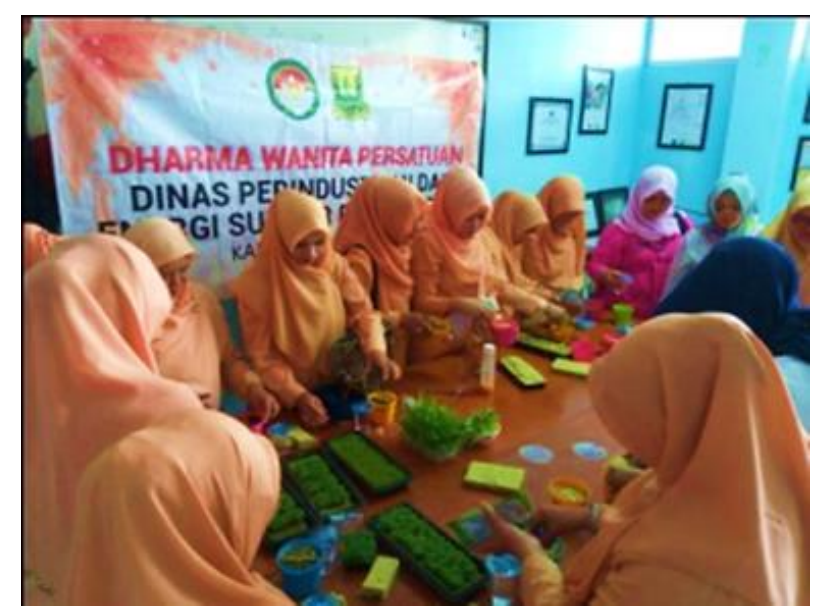

Gambar 4. Peserta pelatihan dari unsur Darma Wanita Persatuan sedang praktik langsung per individu

Berdasarkan hasil monitoring diketahui bahwa hampir semua microgreens yang ditanam peserta tumbuh dengan baik. Cara usaha tani yang mudah bahkan tanpa memerlukan pupuk semakin memperingan para ibu rumah tangga dalam merawat microgreens. Penambahan pupuk justru akan memperlambat pertumbuhan microgreens (Weber, 2017). Hanya saja sebagai tindak lanjut kegiatan belum semua ibu rumah tangga secara berkelanjutan melaksanakan usaha tani microgreens di rumah tangganya masing-masing dalam rangka pemenuhan kebutuhan sayuran sehat bagi keluarga karena berbagai alasan. Alasan tersebut diantaranya adalah perlunya adapatasi lebih lama pada anggota 
keluarga untuk membiasakan diri mengkonsumsi sayuran mini (microgreens). Hal ini wajar saja karena sayuran microgreen umumnya memiliki rasa yang eksotis dan menyengat, bisa netral, pedas, pahit, asam, atau bahkan bercita rasa rempah yang kuat (tergantung jenis sayurannya). Sehingga perlu pembiasaan terlebih dahulu agar semua keluarga dapat terbiasa mengkonsumsinya.

Microgreens memiliki potensi baik secara ekonomi. Apabila usaha taninya ditekuni secara serius, bukan hanya dapat memenuhi kebutuhan sayuran sehat keluarga, tetapi juga dapat menghemat belanja sayuran keluarga dan bila dikembangkan aspek bisnisnya akan menguntungkan. Menurut Irawati (2017), sayuran microgreens merupakan menu healthy food di hotel dan restoran. Sebagai sayuran muda, microgreens masih mengandung vitamin, mineral, antioksidan, betakaroten, minyak nabati, dan protein yang lebih lengkap daripada sayuran dewasa. Hal ini diperkuat oleh Braunstein (2013) yang menyatakan bahwa microgreens sebagai sayuran muda mengandung empat hingga enam kali lipat vitamin dan phytochemical dari yang ditemukan pada daun dewasa pada tanaman yang sama jenisnya. Biasanya, di hotel sayuran microgreens disajikan dalam bentuk salad. Selain itu sayuran microgreens juga dapat disajikan dalam bentuk jus sayur atau sebagai topping pada sajian makanan lainnya. Jenis sayuran yang biasa disajikan diantaranya bayam hijau, bayam merah, lettuce, bassile, kemangi, seledri, brokoli, dan kol. Melihat peluang yang cukup menjanjikan dari usaha tani microgreens ini, kiranya perlu kegiatan pengabdian ini dilaksanakan lebih luar lagi ke kalangan umum agar microgreens ini bukan hanya dikenal sebagai sayuran sehat yang populer tetapi juga agar semua kalangan mengetahui manfaat dan dapat mengusahakannya secara mandiri.

\section{KESIMPULAN}

Usaha tani microgreens dapat menjadi pilihan alternatif sebagai kegiatan para ibu tangga dalam rangka memenuhi kebutuhan sayuran sehat dan mengurangi pengeluaran keluarga. Kegiatan Pengabdian kepada msasyarakat ini dari mulai pemberian materi, praktek hingga monitoring hasil kegiatannya dapat terlaksana dengan baik tetapi masih perlu ditindaklanjuti lagi agar usaha tani microgreens ini dapat terlaksana secara berkelanjutan di kalangan ibu rumah tangga.

\section{UCAPAN TERIMA KASIH}

Kegiatan pengabdian kepada masysarakat ini dialksanakan atas kerjasama banyak pihak khususnya dengan sumber pembiayaan internal dari laboratorium Prodi Agribisnis serta LPPM Universitas Muhammadiyah Sukabumi. Ucapan terima kasih disampaikna pada semua pihak yang terlbat aktif dalam kegiatan, diantaranya LPPM dan Laboratorium Agribisnis Universitas Muhammadiyah Sukabumi, Agribusiness Development Center (ADC), Ranting Aisyiyah Cigunung, Pimpinan Daerah Aisyiyah Kota Sukabumi, Pimpinan Daerah Aisyiyah Kabupaten Sukabumi, DWP Dinas Perindustrian dan Sumber Daya dan Mineral Kabupaten Sukabumi, dan DWP Dinas Ketahanan Pangan Kabupaten Sukabumi.

\section{REFERENSI}

Braunstein, M.M. 2013. Microgreen Garden: An Indoor Grower's Guide to Gourmet Greens. Summertown: Book Publishing Company.

Febriani, V., Nasrika, E., Munasari, T., Permatasari, Y., Widiatningrum, T. 2019. Analisis Produksi Microgreens Brassica oleracea Berinovasi Urban Gardening Untuk Peningkatan Mutu Pangan Nasional. Journal of Creativity Student. 2(2):58-66. 
Foilyani, F.H., Idris, A., Swasto, B. 2009. Pemberdayaan Perempuan Perdesaan Dalam Pembangunan (Studi Kasus Perempuan Di Desa Samboja Kuala, Kecamatan Samboja, Kabupaten Kutai Kertanegara). Wacana: Jurnal Penelitian IlmuIlmu Sosial. 12(3):592-608.

Hamzens, W.P.S., Moestopo, M.W. 2018. Pengembangan Potensi Pertanian Perkotaan Di Kawasan Sungai Palu. Jurnal Pengembangan Kota. 6(1):7583. https://doi.org/10.14710/jpk.6.1.75-83

Hong, J., Gruda, N.S. 2020. The Potential of Introduction of Asian Vegetables in Europe. Horticulturae. 6(3):38.

https://doi.org/10.3390/horticulturae603003 8

Irawati, N. 2017. Microgreens sebagai Trend Healthy Food di Hotel dan Restoran Yogyakarta. Kepariwisataan: Jurnal Ilmiah. 11(2):59-68.

Irsyadillah, I. 2014. Politics of Education. Jurnal Serambi Edukasi. 2(2):1-6.

Manembu, A.E. 2017. Peranan Perempuan Dalam Pembangunan Masyarakat Desa (Suatu Studi di Desa Maumbi Kecamatan Kalawat Kabupaten Minahasa Utara). Politico : Jurnal Ilmu Politik. 6(1):1-28.

Mir, S.A., Shah, M.A., Mir, M.M. 2017. Microgreens: Production, shelf life, and bioactive components. Critical Reviews in Food Science and Nutrition. 57(12):2730-2736. https://doi.org/10.1080/10408398.2016.11445 57

Pinto, E., Almeida, A.A., Aguiar, A.A., Ferreira, I.M. 2015. Comparison between the mineral profile and nitrate content of microgreens and mature lettuces. Journal of Food Composition and Analysis. 37:38-43. https://doi.org/10.1016/j.jfca.2014.06.018

Renna, M., Paradiso, V.M. 2020. Ongoing Research on Microgreens: Nutritional Properties, ShelfLife, Sustainable Production, Innovative Growing and Processing Approaches. Foods. 9(6):826. https://doi.org/10.3390/foods9060826

Sya'roni, R.S. 2002. Membangun Keberdayaan Komunitas Pantai Untuk Pengelolaan Sumber Daya Laut Pengalaman Fasilitasi Kelompok
Masyarakat Pantai Prigi Jawa Timur. Jurnal Analisis Sosial. 7(2):1-8.

Turner, E.R., Luo, Y., Buchanan, R.L. 2020. Microgreen nutrition, food safety, and shelf life: A review. Journal of Food Science. 85(4):870-882. https://doi.org/10.1111/1750-3841.15049

Weber, C.F. 2017. Microgreen Farming and Nutrition: A Discovery-Based Laboratory Module to Cultivate Biological and Information Literacy in Undergraduates. The American Biology Teacher. 79(5):375-386. https://doi.org/10.1525/abt.2017.79.5.375

Widiwurjani, W., Guniarti, G., Andansari, P. 2019. Status Kandungan Sulforaphane Microgreens Tanaman Brokoli (Brassica oleracea L.) Pada Berbagai Media Tanam Dengan Pemberian Air Kelapa Sebagai Nutrisi. Jurnal Ilmiah Hijau Cendekia. 4(1):34-38. https://doi.org/10.32503/hijau.v4i1.471 